\title{
Evaluation of small intestinal damage in a rat model of 6 Minutes cardiac arrest
}

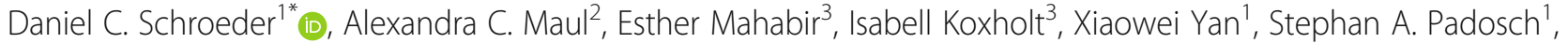 \\ Holger Herff', Insa Bultmann-Mellin², Anja Sterner-Kock², Thorsten Annecke' ${ }^{1}$, Tim Hucho' ${ }^{1}$, Bernd W. Böttiger ${ }^{1}$ \\ and Maria Guschlbauer ${ }^{2,4}$
}

\begin{abstract}
Background: Contribution of the small intestine to systemic inflammation after cardiac arrest (CA) is poorly understood. The objective was to evaluate whether an in vivo rat model of 6 min CA is suitable to initiate intestinal ischaemia-reperfusion-injury and to evaluate histomorphological changes and inflammatory processes in the small intestinal mucosa resp. in sera.

Methods: Adult male Wistar rats were subjected to CA followed by cardio-pulmonary resuscitation. Proximal jejunum and serum was collected at 6 h, 24 h, $72 \mathrm{~h}$ and $7 \mathrm{~d}$ post return of spontaneous circulation (ROSC) and from a control group. The small intestine was evaluated histomorphologically. Cytokine concentrations were measured in jejunum lysates and sera.

Results: Histomorphological evaluation revealed a significant increase in mucosal damage in the jejunum at all timepoints compared to controls $(p<0.0001)$. In jejunal tissues, concentrations of IL-1a, IL-1 $\beta$, IL-10, and TNF-a showed significant peaks at $24 \mathrm{~h}$ and were 1.5- to 5.7-fold higher than concentrations at $6 \mathrm{~h}$ and in the controls $(p<0.05)$. In serum, a significant higher amount of cytokine was detected only for IL-1 $\beta$ at $24 \mathrm{~h}$ post-ROSC compared to controls (15.78 vs. $9.76 \mathrm{pg} / \mathrm{ml})$.

Conclusion: CA resulted in mild small intestinal tissue damage but not in systemic inflammation. A rat model of 6 min CA is not capable to comprehensively mimic a post cardiac arrest syndrome (PCAS). Whether there is a vital influence of the intestine on the PCAS still remains unclear.
\end{abstract}

Keywords: Cardiac arrest, Small intestine, Ischaemia-reperfusion-injury, Systemic inflammatory response syndrome

\section{Background}

Cardiac arrest (CA) results in transient systemic ischaemia followed by reperfusion as a consequence of successful resuscitation. First, cessation of circulation results in depletion of oxygen followed by ATP-dependent $\mathrm{Na}^{+} / \mathrm{K}^{+}$-pump dysfunction. Resulting in a breakdown of cellular integrity, glutamate is being released intracellularly and mediates cerebral excitotoxicity by activation of N-methyl-D-aspartate receptors. Subsequently, intracellular $\mathrm{Ca}^{++}$influx and activation of caspases, phospholipases, and proteases lead to cellular death [1]. Secondly, subsequent reperfusion triggers formation of free radicals, which further

\footnotetext{
* Correspondence: Daniel.Schroeder@uk-koeln.de

${ }^{1}$ Department of Anaesthesiology and Intensive Care Medicine, University

Hospital of Cologne, Kerpener Str. 62, Cologne, Germany

Full list of author information is available at the end of the article
}

aggravates cell death. Later, accumulation of inflammatory cytokines is initiated and causes a long-lasting inflammatory reaction.

Within 4-5 min after CA, selectively vulnerable regions in the brain such as the hippocampal CA1 become apoptotic and necrotic [2]. As a result, brain injury is responsible for the mortality of $68 \%$ of the victims of CA [3]; neurocognitive long-term impairment occurs in half of the survivors [4]. In addition to that, within hours to days, the characteristic systemic ischaemia-reperfusion-injury provokes a systemic inflammatory release also known as sepsis-like- or post-cardiac arrest syndrome (PCAS) ending up in multiple organ failure $[5,6]$. In fact, CA is a complex systemic ischaemia-reperfusion-injury with contribution of multiple independent tissue. However, to date, particular contribution of peripheral organs to the

(C) The Author(s). 2018 Open Access This article is distributed under the terms of the Creative Commons Attribution 4.0 International License (http://creativecommons.org/licenses/by/4.0/), which permits unrestricted use, distribution, and 
development of PCAS is not clearly understood. Given that more than $30 \%$ of victims of CA show bacteremia upon presentation, the small intestine was discussed to be an immediate by-product of a systemic ischaemiareperfusion-injury $[7,8]$.

As described, the small intestine is highly susceptible to a focal ischaemia-reperfusion-injury $[9,10]$. Already after 15-30 min of mesenterial occlusion, morphological changes such as atrophy of the villi and damage of tunica mucosa and tunica serosa appear [11]. Consequently, loss of intestinal integrity is associated with excessive fluid loss and translocation of gut bacteria and toxins into the blood circulation [12]. Subsequent restoration of blood flow leads to an activation of molecular and cellular components of the innate immunity resulting in an inflammatory response [13]. As a result, local and systemic inflammation occurs and causes a multiple organ dysfunction syndrome with a mortality rate reported between $30-90 \%[9,10,13-15]$.

However, due to the predominant brain damage decisive for morbidity and mortality in survivors of CA the role of the small intestine in the development of systemic inflammation after CA was not intensively investigated yet. Thus, the objective was (i) to evaluate whether an in vivo rat model of $6 \mathrm{~min} \mathrm{CA}$ is suitable to initiate an intestinal ischaemia-reperfusion-injury to further examine (ii) genesis of local and systemic inflammation. It was hypothesized that mild small intestinal damage occurs even after short durations of CA and resuscitation.

\section{Methods}

\section{Animals and husbandry}

Seventy-eight 7 to 8 weeks old male Wistar rats (Janvier, France) weighing 280 - $320 \mathrm{~g}$ were transferred into the animal facility 10 days before surgery and had ad libitum access to standard pelleted feed (Ssniff ${ }^{\circ}$, V1534-703, Germany) and water. Rats were housed under a 12:12 h light-dark cycle at $22{ }^{\circ} \mathrm{C}$ and a relative humidity of $60 \%$. They were allocated randomly to 5 groups (controls, $6 \mathrm{~h}$, $24 \mathrm{~h}, 72 \mathrm{~h}$ and $7 \mathrm{~d}$ post-ROSC).

\section{Cardiac arrest and cardio-pulmonary resuscitation}

The detailed experimental protocol was previously published by Böttiger et al. [16]. Briefly, rats were anesthetized with $3 \%$ sevoflurane and $70 \%$ nitrous oxide in oxygen. Animals were endotracheal intubated (Braunüle-MT No. 3, Braun, Germany) and ventilated at a rate of 60 breaths per min (Rodent Ventilator, Harvard Apparatus, MA, USA). A saline-filled polyethylene catheter was advanced via cut-down into the left femoral artery to continuously measure mean arterial pressure (MAP, SC7000, Siemens Health Care $\mathrm{GmbH}$, Germany). Another saline-filled polyethylene catheter was advanced via cut-down into the left femoral vein for drug administration. The tidal breathing volume was adjusted to ensure a physiological $\mathrm{pCO}_{2}$
(35-45 mmHg). The inspired oxygen concentration $\left(\mathrm{FiO}_{2}\right)$ was regulated to ensure a physiological $\mathrm{pO}_{2}$. Blood gas analysis was performed using ABLFlex800 (Radiometer, Germany). The cardio-pulmonary resuscitation (CPR) protocol fulfils the Utstein Style guidelines for laboratory CPR research [17]. The rats received an oesophageal electrode for induction of ventricular fibrillation $(12 \mathrm{~V}, 50 \mathrm{~Hz}$, $1.5 \mathrm{~min}$ ) until the mean arterial blood pressure stayed below $15 \mathrm{mmHg}$ [18]. After $5.5 \mathrm{~min}$ of CA, rats were mechanically ventilated using $100 \%$ oxygen at 60 breaths per min. At 6 min after CA, CPR started by performing a manual closed-chest cardiac massage (200 times/min) and an injection of $20 \mu \mathrm{g} / \mathrm{kg}$ epinephrine (Suprarenin, SanofiAventis, Germany). Two min later, a single bi-phasic shock of 2-3 J (M series, Zoll Corporation, Germany) was attempted. Epinephrine administration and biphasic shocks were repeated every $30 \mathrm{~s}$. ROSC was defined as maintenance of mean arterial blood pressure above $50 \mathrm{mmHg}$ for at least $10 \mathrm{~min}$. If ROSC was not achieved after $6 \mathrm{~min}$ of CPR, resuscitation procedures were terminated. To maintain normocapnia, ventilation rate was adjusted and sodium bicarbonate was titrated according to the blood gas analysis. Once adequate spontaneous breathing was observed, rats were extubated, kept singly and monitored every $2-4 \mathrm{~h}$.

\section{Euthanasia and tissue sampling}

A total of 55 rats $(70.5 \%)$ could not be resuscitated. All 23 successfully resuscitated and sham-operated rats survived the observation period and were included in the study. The number of rats used for histomorphological analysis and cytokine profiling is shown in Table 1. One group was used as sham-operated control-group and was euthanized immediately after surgical procedures without $\mathrm{CA}$ and CPR. Under anesthesia, the thorax was opened and blood samples were taken from the left ventricle. Following coagulation for $45 \mathrm{~min}$ at room temperature, the tubes (Eppendorf, Germany) were centrifuged for $10 \mathrm{~min}$ at $2500 \mathrm{~g}$ and $4{ }^{\circ} \mathrm{C}$. sera were aliquoted and stored

Table 1 Number of rats used for histomorphological analysis $(\mathrm{HA})$ and cytokine profiling (CP) of controls (C) and at 6 h, 24 h, $72 \mathrm{~h}$ and $7 \mathrm{~d}$ post-ROSC

\begin{tabular}{llllll}
\hline & \multicolumn{5}{l}{ Study groups and number of rats } \\
\cline { 2 - 6 } Analysis & $\mathrm{C}$ & $6 \mathrm{~h}$ & $24 \mathrm{~h}$ & $72 \mathrm{~h}$ & $7 \mathrm{~d}$ \\
\hline Jejunum HA & 4 & 3 & 5 & 4 & 4 \\
Jejunum CP & 4 & 3 & 5 & 6 & 4 \\
Serum CP & 6 & 3 & 6 & 4 & 4
\end{tabular}

This analysis is a sub-study of an investigation aimed to pursue systemic inflammation in multiple tissues after CA. Serum cytokine profiling was conducted in $n=23$ rats. Only $n=3$ animals were resuscitated and included in the $6 \mathrm{~h}$ group. At least $n=4$ animals were included in the $24 \mathrm{~h}, 72 \mathrm{~h}$ and $7 \mathrm{~d}$ group. Additionally, $n=2$ more sera in the control group and 1 more serum sample in the $24 \mathrm{~h}$ group were collected and analyzed from further experiments. In the $72 \mathrm{~h}$ group, $\mathrm{n}=2$ more jejunal samples were also analyzed 
at $-80{ }^{\circ} \mathrm{C}$. A $2-3 \mathrm{~cm}$ piece of the mid jejunum, $8 \mathrm{~cm}$ distal from the pylorus, was excised and divided. One segment was shock-frozen in liquid nitrogen and stored at $-80{ }^{\circ} \mathrm{C}$ for the multiplex cytokine assay. The other segment was fixed in $4 \%$ formalin for histomorphological studies.

\section{Histomorphological analysis - Chiu grading}

Paraffin-embedded jejunal tissue was sectioned $(4 \mu \mathrm{m})$ and stained with hematoxylin and eosin (H\&E) according to standard protocols. The morphological integrity of the intestinal wall was classified by a blinded investigator using a modified protocol according to Chiu et al. [19]: Grade 0: normal mucosa; Grade 1: development of a sub-epithelial space at the tips of the villi; Grade 2: more extended sub-epithelial space at the tips of the villi, development of Gruenhagen's space at the tips of the villi; Grade 3: massive epithelial lifting down the sides of the villi, villus necrosis; Grade 4: villi are denuded of epithelial layer; Grade 5: loss of villi, mucosal ulceration and necrosis with invasion of the muscularis propria. To evaluate oedema formation within the jejunal wall, the thickness of serosa, muscularis, submucosa and mucosa was measured using 10-fold magnifications (Olympus DP25, cellSens Standard 1.11, Olympus GmbH, Germany).

\section{Tissue lysates and protein extraction}

Proteins were extracted by homogenizing $200 \mathrm{mg}$ jejunal tissue with $500 \mu \mathrm{l}$ RIPA buffer $(150 \mathrm{mM} \mathrm{NaCl}, 1 \%$ Triton-x-100, 1\% Na-deoxycholate, $0.1 \%$ SDS, $50 \mathrm{mM}$ Tris- $\mathrm{HCl} \mathrm{pH} 8,10 \mathrm{mM}$ EDTA) containing a proteinaseinhibitor (complete Mini, EDTA-free, Roche, Switzerland). Subsequently, the tissue lysates were centrifuged for $15 \mathrm{~min}$ at $11000 \mathrm{~g}$ and $4{ }^{\circ} \mathrm{C}$ and supernatants were centrifuged for $40 \mathrm{~min}$ at $44,400 \mathrm{~g}$ and $4{ }^{\circ} \mathrm{C}$. The clear supernatants were analyzed using the BCA test (Pierce, Thermo Scientific, Germany) and duplicate aliquots of $1000 \mu \mathrm{g} / \mathrm{ml}$ protein were measured directly.

\section{Multiplex cytokine assay}

IL-1 $\alpha$, IL-1 $\beta$, IL-6, IL-10 and TNF- $\alpha$ in jejunal tissues and IL-1 $\alpha$, IL-1 $\beta$, IL-2, IL-4, IL-5, IL-6, IL-10, IL-12 (p70), IL-13, interferon- $\gamma$ (IFN- $\gamma$ ), granulocyte macrophage colony-stimulating factor (GM-CSF) and TNF- $\alpha$ in serum were measured in duplicates in a multiplex analyzer (Bio-Plex $200^{\circ}$, Bio-Rad Laboratories, USA) according to the manufacturer's instructions. The jejunal tissue lysate protein was diluted 1:2 with sample diluent containing $0.5 \%$ BSA $(500 \mu \mathrm{g} / \mathrm{ml}$ final protein concentration). Sera were thawed, centrifuged for $5 \mathrm{~min}$ at $10,000 \mathrm{~g}$ and $4{ }^{\circ} \mathrm{C}$ and diluted 1:4 in sample diluent. By using the median fluorescence intensity and the standard curve, the absolute concentration of each cytokine $(\mathrm{pg} / \mathrm{ml})$ was calculated (Bio-Plex Manager 6.1, Bio-Rad Laboratories).
The value 0 was attributed when the results were below the detection limit.

\section{Statistical analyses}

An a priori power analysis was performed to determine the adequate sample size for detection of TNF- $\alpha$ in serum $24 \mathrm{~h}$ after $\mathrm{CA}$ as primary outcome variable. (type 1 error: $5 \%(\alpha<0.05)$; type 2 error: $20 \%(\beta<0.80)$; medium efficiency: 0.6). Animal studies reporting serum TNF- $\alpha$ concentrations after $\mathrm{CA}$ due to ventricular fibrillation are scarce. According to the literature, an average rise from 0 to approximately $12 \mathrm{pg} / \mathrm{mL}$ [5] in humans is expected. Since no serum TNF- $\alpha$ was expected on day 0 (controls), a variability of 0 was expected. To display a difference in serum TNF- $\alpha$ concentrations, we estimated a number of 4 rats per group.

One-way ANOVA and Tukey's multiple comparison test was performed using GraphPad Prism 6 for Windows. For correlation of the duration of CA with cytokine concentrations and Chiu-grades, the Pearson's correlation test was used with unilateral values (GraphPad Software, USA). All data are presented as mean \pm SD. A $p$-value $<0.05$ was considered statistically significant.

\section{Ethical statement}

All procedures were ethically approved by the appropriate governmental authority (Landesamt für Natur, Umwelt und Verbraucherschutz Nordrhein-Westfalen, LANUV, Germany, AZ: 8.87-51.04.20.09.368) and were in accordance with the German Animal Welfare Law. Animal care and use was performed by qualified individuals, supervised by a veterinarian. All facilities and transportation complied with current legal requirements. The manuscript complies with the Animals in Research: Reporting In Vivo Experiments (ARRIVE) guidelines [20]. Humane endpoints were specified and part of the animal welfare application according to the directive 2010/63/EU of the European parliament. A list of specific clinical signs to determine the animal's physiology and behavioral condition was used. Specific experiment-related humane endpoints such as neurological disturbances, lameness, wound healing deficits and coma were evaluated. The animals were scored as mild, moderate or severely impaired. According to the results of scoring, animals were treated (analgesics, antibiotics), frequently examined or sacrificed (severe impairment). According to the results of the scored humane endpoints, animals received $50 \mu \mathrm{g} / \mathrm{ml}$ meloxicam p.o. within the first three days after ROSC, if necessary.

\section{Results}

Histomorphological analysis - Chiu grading

Representative images of intestinal tissues after CA revealing Chiu grades from 0 to 5 are shown in Fig. 1a-f. Controls lacked histomorphological changes in the small 
A

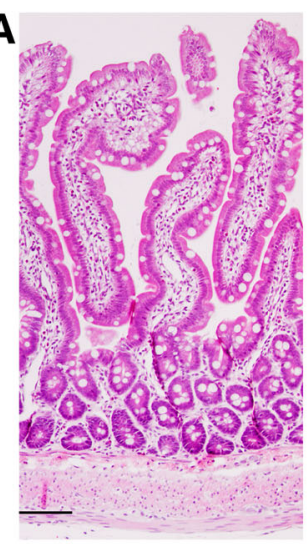

D

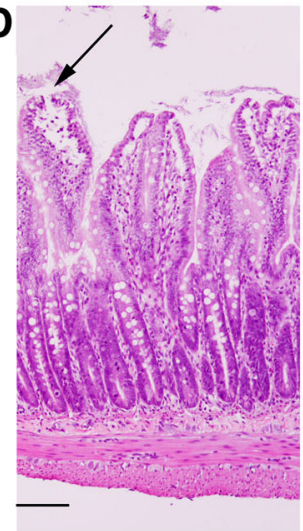

B

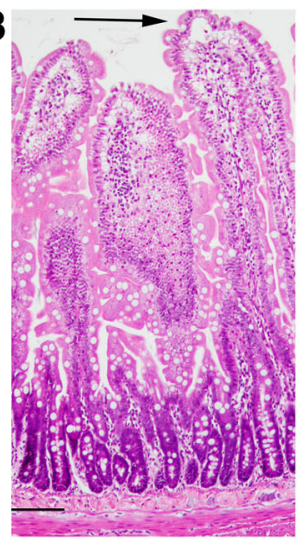

E

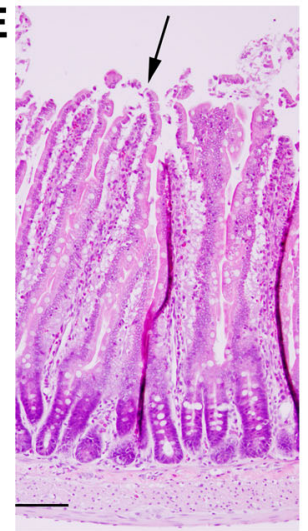

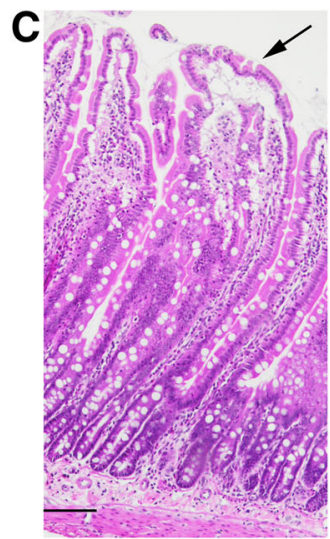

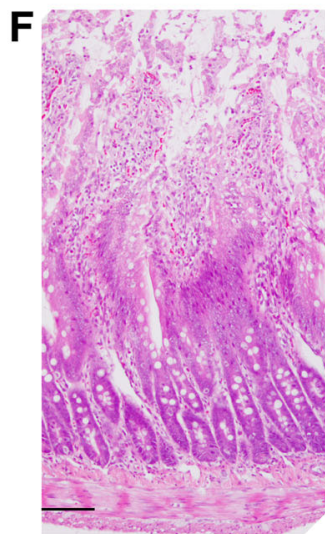

Fig. 1 Histomorphological evaluation of the jejunal wall of rats after 6 min of CA using a modified Chiu scoring system (Chiu et al. 1970) [44]. Images represent the Chiu grades $0-5$. a Intact mucosa and villus structures in control tissue of sham-operated rats (Chiu grade 0). b Development of a sub-epithelial space at the tips of the villi (arrow) $24 \mathrm{~h}$ post-ROSC (Chiu grade 1). $\mathbf{c}$ Development of a Gruenhagen's space at the tip of a villus (arrow) $24 \mathrm{~h}$ post-ROSC (Chiu grade 2). $\mathbf{d}$ Villus necrosis (arrow) $7 \mathrm{~d}$ post-ROSC (Chiu grade 3). e Massive epithelial desquamation and villi which are denuded of epithelial layer (arrow) $7 \mathrm{~d}$ post-ROSC (Chiu grade 4). $\mathbf{f}$ Loss of villi, mucosal ulceration and necrosis $7 \mathrm{~d}$ post-ROSC (Chiu grade 5). a-f Hematoxilin-eosin staining, longitudinal section of $4 \mu \mathrm{m}$ thickness (a, e, f) or cross section (b, c, d), scale bars represent $100 \mu \mathrm{m}$

intestine. In rats with $6 \mathrm{~min}$ of $\mathrm{CA}$, the intestinal $\mathrm{mu}$ cosa revealed desquamation of the villus tips. Blunt, dome-shaped, fenestrated epithelial cells of submucosal arterioles were evident. Gruenhagen's spaces, slight perivascular oedema, hydropic generation of epithelial cells and sparse pyknotic cells were identified. Chiu grades of jejunal mucosa revealed a significant time-dependent effect (Fig. 2, $p<0.0001$ ). Tukey's multiple comparison test showed a significant increase (12.5-fold) in mucosal damage $6 \mathrm{~h}$ post-ROSC $(3.13 \pm 0.64)$ compared to controls $(0.25 \pm 0.5, p<0.001)$. Mucosal damage decreased significantly 2.1 -fold at $24 \mathrm{~h}(1.48 \pm 0.87)$ compared to $6 \mathrm{~h}$ post-ROSC $(3.13 \pm 0.64, p<0.05)$. Chiu grading decreased significantly 2.2 -fold at $72 \mathrm{~h}(1.4 \pm 0.46)$ compared to $6 \mathrm{~h}$ post-ROSC $(p<0.05)$. At $7 \mathrm{~d}$ post-ROSC, Chiu grade increased again $(3.33 \pm 0.69, p<0.05)$ compared to $24 \mathrm{~h}$ $(1.48 \pm 0.87)$ and was the highest compared to controls $(0.25 \pm 0.5, p<0.0001)$.

Comparing the intestinal wall thickness of controls to that at $6 \mathrm{~h}, 24 \mathrm{~h}, 72 \mathrm{~h}$ and $7 \mathrm{~d}$ post-ROSC showed

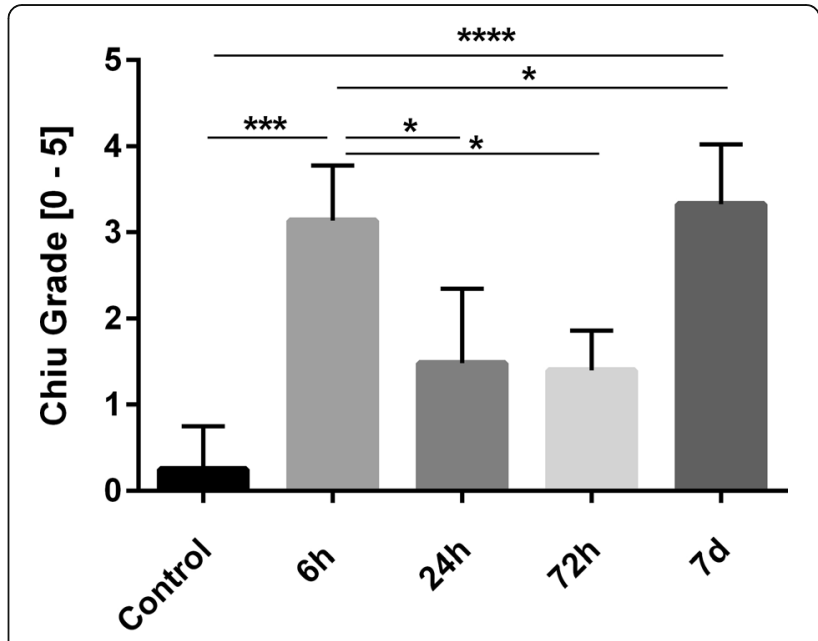

Fig. 2 Chiu Scoring. Chiu Scoring [Grades 0-5] in jejunum of controls and at $6 \mathrm{~h}, 24 \mathrm{~h}, 72 \mathrm{~h}$ and $7 \mathrm{~d}$ post-ROSC are expressed as mean \pm SD. One-way ANOVA $p<0.0001$. Tukey's multiple comparison test is marked with asterisks $\left({ }^{*} p<0.05,{ }^{* * *} p<0.001,{ }^{* * * *} p<0.0001\right)$ 
significant time-dependent changes $(p<0.0001)$. Tukey's multiple comparison test showed that the muscularis was significantly thinner at $7 \mathrm{~d}$ post-ROSC compared to controls $(p<0.05)$. A thinner muscularis was also observed $6 \mathrm{~h}, 24 \mathrm{~h}$ and $72 \mathrm{~h}$ post-ROSC but this difference was not significantly decreased compared to controls.

\section{Multiplex cytokine assay Jejunal tissue}

In jejunal tissue, IL-1 $\alpha$ was altered over time with peak values at $24 \mathrm{~h}$ post-ROSC. $(p<0.01$, Fig. 3a). Tukey's multiple comparison test identified significant elevations in IL- $1 \alpha$ at $24 \mathrm{~h}$ compared to controls (1.7-fold increase, $p<0.01$,) and the $6 \mathrm{~h}$ group (1.7-fold increase, $p<0.05$ ). At $72 \mathrm{~h}$, IL- $1 \alpha$ concentration decreased significantly 1.6 -fold $(p<0.01)$ compared to the $24 \mathrm{~h}$ group. No significant difference was detected between $24 \mathrm{~h}$ and $7 \mathrm{~d}$ post-ROSC (Fig. 3a). IL-1 $\beta$ showed significant time-dependent changes $(p<0.01)$. IL-1 $\beta$ peaked at $24 \mathrm{~h}$ compared to controls (5.7-fold increase, $p<0.05$ ) and $6 \mathrm{~h}$ (7.9-fold increase, $p<0.05)$. At $72 \mathrm{~h}, \mathrm{IL}-1 \beta$ was 2.5 -fold lower than at $24 \mathrm{~h}$ and 1.9-fold lower than at $7 \mathrm{~d}$ post-ROSC but differences were not statistically different (Fig. 3b). IL-6 concentrations showed time-dependent changes $(p<0.01)$. Additionally, a significant 1.2-fold decrease was detected at $72 \mathrm{~h}$ compared to $24 \mathrm{~h}$ post-ROSC ( $p<0.01$, Fig. 3c). IL-10 concentrations revealed significant time-dependent changes $(p<0.0001)$. At $24 \mathrm{~h}$, it peaked significantly compared to controls $(p<0.0001)$ and $6 \mathrm{~h}$ post-ROSC $(p<0.001)$ resulting in a 2.2 -fold and 1.9-fold increase, respectively. Concentrations at $72 \mathrm{~h}(1.6$-fold, $p<0.001)$ and $7 \mathrm{~d}(1.5$-fold, $p<0.05)$ decreased significantly compared to that at $24 \mathrm{~h}$ (Fig. 3d). TNF- $\alpha$ concentrations showed a significant time-dependent effect $(p<0.01)$ at $24 \mathrm{~h}$ post-ROSC compared to controls (1.5-fold increase, $p<0.01)$ and $6 \mathrm{~h}$ post-ROSC (1.4-fold increase, $p<0.05)$. TNF- $\alpha$ decreased significantly at $72 \mathrm{~h}$ post-ROSC compared to $24 \mathrm{~h}$ post-ROSC $(1.5$-fold, $p<0.01)$. There were no significant changes between $72 \mathrm{~h}$ and $7 \mathrm{~d}$ post-ROSC (Fig. 3e).

\section{Serum}

Absolute concentrations of IL-2, IL-4, IL-5, IL-12 (p70), IL-13, GM-CSF and IFN- $\gamma$ in serum are shown in Table 2. Results for IL- $1 \alpha$, IL-1 $\beta$, IL- 6 , IL-10 and TNF- $\alpha$ are shown in Fig. 3f-j. Serum concentrations of IL- $1 \alpha$, IL-2, IL-4, IL-5, IL-6, IL-10, IL-12 (p70), IL-13, GM-CSF, IFN- $\gamma$ and TNF- $\alpha$ did not differ significantly between controls and at $6 \mathrm{~h}, 24 \mathrm{~h}, 72 \mathrm{~h}$ and $7 \mathrm{~d}$ post-ROSC. IL-1 $\beta$ showed a significant time-dependent effect $(p<$ $0.05)$. At $24 \mathrm{~h}$ post-ROSC, IL-1 $\beta$ significantly increased 1.6 -fold compared to controls $(p<0.05$, Fig. $3 \mathrm{~g})$.
Comparison of jejunum and serum cytokine concentrations The ratio of absolute cytokine concentrations in jejunum compared to serum is shown in Table 3. Overall, significant higher IL- $1 \alpha$ and TNF- $\alpha$ concentrations were observed in jejunal tissue compared to serum in both controls and CA groups at all timepoints $(p<0.05)$. IL-1 $\beta$ in controls and at $24 \mathrm{~h}$ post-ROSC, IL- 6 at $24 \mathrm{~h}$ postROSC and IL-10 at $24 \mathrm{~h}$ and $72 \mathrm{~h}$ post-ROSC were also significantly higher in jejunum lysates compared to serum. Increased concentrations of IL-1 $\beta$ at $72 \mathrm{~h}$ and $7 \mathrm{~d}$ post-ROSC and IL-10 in controls and at $6 \mathrm{~h}$ and $7 \mathrm{~d}$ post-ROSC were detected in jejunum but were not significantly different. IL- 6 concentrations in jejunum and serum in controls and at $6 \mathrm{~h}, 72 \mathrm{~h}$ and $7 \mathrm{~d}$ post-ROSC and IL- $1 \beta$ concentrations at $6 \mathrm{~h}$ post-ROSC were comparable. Comparing the time-dependent profiles of jejunum/serum ratio with profiles in jejunal tissue, IL-1 $\alpha$, IL-6, IL-10 and TNF- $\alpha$ displayed a similar alteration with a peak at $24 \mathrm{~h}$ post-ROSC while IL-1 $\beta$ peaked at $7 \mathrm{~d}$ post-ROSC, in contrast to jejunal tissue at $24 \mathrm{~h}$ post-ROSC (Fig. 3a-e).

\section{Correlation analysis}

No significant correlation between the duration of CA and cytokine concentrations in jejunum was detected $6 \mathrm{~h}$ and $24 \mathrm{~h}$ post-ROSC: $6 \mathrm{~h}$ group: IL- $1 \alpha: r=0.43, p=$ 0.546; IL-1 $\beta: r=0.002, p=0.970$; IL-6: $r=0.06, p=0.848$; IL-10: $r=0.44, p=0.532$; TNF- $\alpha: r=0.07, p=0.824 .24 \mathrm{~h}$ group: IL- $1 \alpha: r=0.01, p=0.874$; IL-1 $\beta: r=0.26, p=$ 0.492; IL-6: $r=0.86, p=0.073$; IL-10: $r=0.34, p=0.413$; TNF- $\alpha: r=0.32, p=0.438$. However, there was a statistically significant correlation between the duration of CA and the Chiu-Grade $7 \mathrm{~d}$ after CA $(r=0.97, p=0.012)$, while the other timepoints were not statistically significant (6 h group: $r=0.85, p=0.251 ; 24$ h group: $r=0.24$, $p=0.501 ; 72$ h group: $r=0.21, p=0.537$ ). Additional information pertaining to the duration of cardiac arrest and the different groups are shown in Additional file 1 but no significant differences were found between groups.

\section{Discussion}

This study reveals three major findings: (i) mild intestinal barrier damage could be detected within $24 \mathrm{~h}$ in a rat model of 6 min CA. (ii) only mild local intestinal inflammation could be shown within $24 \mathrm{~h}$ after CA. (iii) a systemic inflammation and thus a potential contribution of the small intestine to systemic inflammation could not be simulated after 6 min of CA in rats.

\section{Intestinal barrier damage}

Although 6 min of transient global ischaemia and subsequent reperfusion led to mucosal damage and decreased thickness of the muscularis in the small intestine, jejunal tissue concentrations of IL- $1 \alpha$, IL- $1 \beta$, IL- 10 and TNF- $\alpha$ 

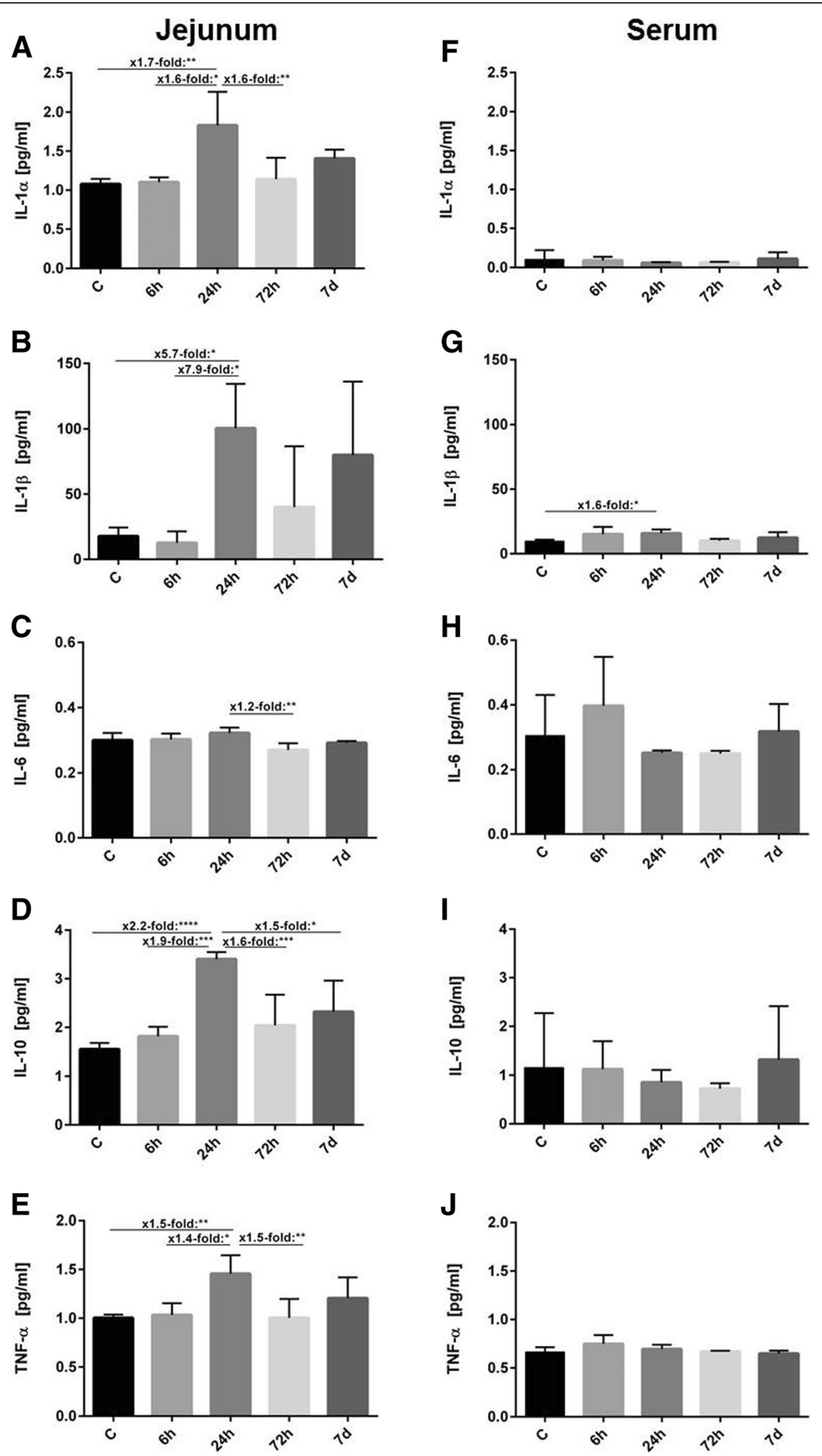

Fig. 3 (See legend on next page.) 
(See figure on previous page.)

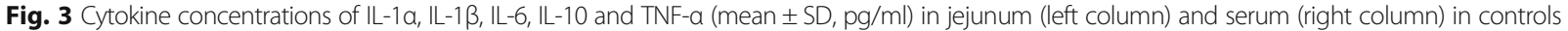
and at $6 \mathrm{~h}, 24 \mathrm{~h}, 72 \mathrm{~h}$ and $7 \mathrm{~d}$ post-ROSC. The significance of Tukey's multiple comparison test is marked with asterisks $\left({ }^{*} p<0.05\right.$, ${ }^{* *} p<0.01$, ${ }^{* * *} p<0.001,{ }^{* * * *} p<0.0001$ ). a IL-1 a concentrations in jejunum (one-way ANOVA $p<0.01$ ). b IL-1 $\beta$ concentrations in jejunum (one-way ANOVA $p<0.01$ ). $\mathbf{c}$ IL-6 concentrations in jejunum (one-way ANOVA $p<0.01$ ). $\mathbf{d} \mathrm{IL}-10$ concentrations in jejunum (one-way ANOVA $p<0.0001$ ). e TNF- $a$ concentrations in jejunum (one-way ANOVA $p<0.01$ ). $\mathbf{f} \| \mathrm{L}-1$ a concentrations in serum (one-way ANOVA $p>0.05$ ). $\mathbf{g} \| \mathrm{L}-1 \beta$ concentrations in serum (one-way ANOVA*). $\mathbf{h} I L-6$ concentrations in serum (one-way ANOVA $p>0.05$ ). $\mathbf{i} \| L-10$ concentrations in serum (one-way ANOVA $p>0.05$ ). $\mathbf{j}$ TNF- $a$ concentrations in serum (one-way ANOVA $p>0.05$ )

were only slightly affected. This result may be due to several reasons.

First, the duration of $6 \mathrm{~min} \mathrm{CA}$ in the present study that is sufficient to show cerebral damage [21] is inadequate to initiate a systemic inflammatory response, which is a clear limitation of this study. As shown by Qian, exceeding the duration of CA of 6 min may extend intestinal damage and influence serum cytokine concentrations. In detail, intestinal microcirculatory blood flow was significantly decreased accompanied by mild elevated serum concentrations of TNF- $\alpha$ and IL- 6 during $8 \mathrm{~min}$ of CA in pigs [22]. In contrast, significant inflammatory response following local ischaemia and reperfusion of the small intestine was shown to be initiated after a duration of at least 15-30 $\mathrm{min}$ [23]. However, models of focal ischaemia and reperfusion are not capable of being translated to conditions of systemic ischaemia and reperfusion. In fact, CA leads to a complex systemic ischaemia-reperfusion-injury with contribution of multiple independent tissues, which are integrated into a complicated cascade of celldeath and systemic inflammation [5, 6].

Secondly, intestinal repair mechanisms seem to be commenced immediately after CA. A normalization of leukocyte-endothelial interaction as well as the wall shear rate was reported to be initiated within $120 \mathrm{~min}$ after CA, which is a period not mirrored in our study [24]. However, reports show that cytokines such as IL-1ra, IL-6, IL-8, IL-10 and TNF- $\alpha$ are expressed within $3 \mathrm{~h}[5,6,25]$ to $6 \mathrm{~h}$ $[24,26]$ and peak within the first 2 days after CA $[5,6]$. This is in line with studies reporting a massive up-regulation of cytokines after ischaemic brain injury [2, 27]. Due

Table 2 Absolute levels of cytokines in serum (IL-2, IL-4, IL-5, IL-12 (p70), IL-13, GM-CSF, IFN- $\gamma$ ) in controls (C) and at 6 h, 24 h, $72 \mathrm{~h}$ and $7 \mathrm{~d}$ post-ROSC expressed in pg/ml (mean \pm SD)

\begin{tabular}{llllll}
\hline & C & $6 \mathrm{~h}$ & $24 \mathrm{~h}$ & $72 \mathrm{~h}$ & $7 \mathrm{~d}$ \\
\hline IL-2 & $0.36 \pm 0.35$ & $0.27 \pm 0.06$ & $0.20 \pm 0.05$ & $0.21 \pm 0.07$ & $0.34 \pm 0.28$ \\
IL-4 & $0.24 \pm 0.18$ & $0.22 \pm 0.09$ & $0.17 \pm 0.02$ & $0.17 \pm 0.02$ & $0.23 \pm 0.10$ \\
IL-5 & n.d. & n.d. & n.d. & n.d. & n.d. \\
IL-12 (p70) & n.d. & n.d. & n.d. & n.d. & n.d. \\
IL-13 & n.d. & n.d. & n.d. & n.d. & n.d. \\
GM-CSF & $0.20 \pm 0.01$ & $0.25 \pm 0.06$ & $0.23 \pm 0.02$ & $0.24 \pm 0.03$ & $0.23 \pm 0.05$ \\
IFN-y & $0.36 \pm 0.07$ & $0.47 \pm 0.18$ & $0.34 \pm 0.01$ & $0.31 \pm 0.02$ & $0.35 \pm 0.05$ \\
\hline
\end{tabular}

n.d. not detected to oxidative stress, NF-KB is up-regulated and orchestrates the release of a number of cytokines such as IL-1ß, IL-2, IL-4, IL-5, IL-6 and IL-10, IL-12, IL-13 and TNF- $\alpha$ $[28,29]$. Accordingly, we collected blood (sera) and tissues at early stages including $6 \mathrm{~h}$ and $24 \mathrm{~h}$ post-ROSC and chose a similar cytokine profile to be investigated. However, in clinical studies, it is often proposed that the PCAS may result from a systemic inflammatory activation persisting for days $[5,30]$. Therefore, cytokine concentrations in jejunum and sera were also evaluated within the first 7 days after CA in the present study.

Third, as repeatedly shown, simulation of a PCAS is difficult in rats and accompanied by a high failure rate of more than $50 \%$ [24, 31]. Thus, on the basis of previous scientific findings, we conclude, that severely injured rats that would develop a PCAS initially died during resuscitation procedures. With a survival rate of only $29.5 \%$ in the present study, we conclude that this model can be utilized to a limited extent to reproduce a PCAS or peripheral tissue damage, respectively. Nevertheless, ROSC rates are comparable to previous experiments performed in our group, which are able to adequately determine cerebral damage $[16,18,21,24,32-34]$. In this pilot study, our main objective was to evaluate peripheral tissue potentially injured due to CA. Notably, we did not lose any animals after ROSC, which is advantageous since post-ROSC mortality is known to be $38 \%$ within an observation period $>48 \mathrm{~h}$ [35]. Interestingly, Vognsen et al. recently showed that only $12 \%$ of animal studies sufficiently report outcome parameters according to the Utstein Guidelines, which was a strong criterion to increase the validity of this study [35].

Given the clinical phenomenon of bacteremia after CA $[7,8]$, intestinal damage seems to be conclusive even after short periods of ischaemia. Congruently, our results point towards a mild local intestinal damage, which is in line with Pan et al. who reported similar Chiu scorings $24 \mathrm{~h}$ after CA of 6 min duration [36]. Likewise, Teschendorf et al. showed a 3-4-fold stronger plasma extravasation from post-capillary mesenteric venules at $120 \mathrm{~min}$ after CA, which is a characteristic sign of endotoxaemia [24]. Another factor taken into consideration is the short initial tissue hyperperfusion followed by a sustained hypoperfusion of intestinal tissue after CA [37, 38]. This inevitably leads to a prolonged period of relative ischaemia 
Table 3 Ratio of absolute IL-1a, IL-1ß, IL-6, IL-10, TNF-a levels in jejunum to absolute levels in serum in controls (C) and at 6 h, 24 h, $72 \mathrm{~h}$ and $7 \mathrm{~d}$ post-ROSC (mean $\pm \mathrm{SD}$ )

\begin{tabular}{llllll}
\hline & $\mathrm{C}$ & $6 \mathrm{~h}$ & $24 \mathrm{~h}$ & $72 \mathrm{~h}$ & $7 \mathrm{~d}$ \\
\hline IL-1a & $15.2 \pm 3.6^{* * * *}$ & $15.5 \pm 1.7^{* * * *}$ & $30.4 \pm 3.8^{* * * * *}$ & $19.3 \pm 4^{* * *}$ & $7.9 \pm 2.9$ \\
IL-1 $\beta$ & $1.7 \pm 0.2^{*}$ & $1 \pm 0.6$ & $6.9 \pm 0.4^{* *}$ & $1 \pm 0.02$ & $10.2 \pm 1.5$ \\
IL-6 & $1 \pm 0.1$ & $1 \pm 0.04$ & $1.3 \pm 0.03^{* * * * *}$ & $3.6 \pm 0.5^{*}$ & $1.1 \pm 0.1$ \\
IL-10 & $1.9 \pm 0.4$ & $1.8 \pm 0.3$ & $4.2 \pm 0.6^{* * * *}$ & $1.7 \pm 0.2^{*}$ & $2.5 \pm 0.7$ \\
TNF-a & $1.5 \pm 0.04^{* * * *}$ & $1.4 \pm 0.1^{*}$ & $2.1 \pm 0.1^{* * *}$ & $2 \pm 0.1^{* *}$ \\
\hline
\end{tabular}

The level of significance is marked with asterisks: $\left.{ }^{*} p<0.05,{ }^{* *} p<0.01{ }^{* * *} p<0.001,{ }^{* * * *} p<0.0001\right)$

where the intestine receives only $5 \%$ of cardiac output [39] and fosters further tissue damage. Interestingly, we found a significant correlation between the duration of CA and the Chiu-grade in the $7 \mathrm{~d}$ group. However, these results should be considered with caution because significant mucosal damage was also shown with a shorter duration of $\mathrm{CA}$ in the $6 \mathrm{~h}$ group (Additional file 1).

It must be noted that mucosal damage and cytokines were not analyzed in animals that could not be resuscitated. However, results were compared to a control group serving as reference. Since achievement of ROSC is mainly dependent on heart function, significant intestinal damage detectable immediately after ceasing CPR was not assumed. As reported, mucosal damage develops within the first 6 to $24 \mathrm{~h}$ after cardiac arrest [36] and may contribute to the development of the PCAS, which was the main objective in this investigation.

\section{Cytokine expression in tissue and serum}

A systemic ischaemia-reperfusion-injury causes a so-called sterile inflammation, which is associated with influx of neutrophils and macrophages, leading to the production of inflammatory cytokines [40]. IL-1 $\alpha$, present in gastrointestinal epithelial and endothelial cells [41], acts via initiation of the inflammatory cascade and is thus a valuable parameter for the determination of inflammatory processes. In the present study, IL- $1 \alpha$ showed a significant increase in the jejunum, resulting in the highest concentrations at $24 \mathrm{~h}$ post-ROSC. At the same timepoint, IL- $1 \alpha$ concentrations in serum were close to detection limits. It has been reported that in vitro circulating IL-1 $\alpha$ was released from endothelial cells [41] but was barely detectable in patients suffering from severe inflammation [42]. This suggests that jejunal and serum IL- $1 \alpha$ concentrations do not necessarily match, as observed in the present study.

The IL-10 family acts protectively during intestinal inflammation by induction of anti-inflammatory effects and inhibition of pro-inflammatory cytokines such as IL-1 $\beta$, IL- 6 and TNF- $\alpha$ [43]. In our study, in jejunal tissues, IL- $1 \alpha$, IL- $1 \beta$ and TNF- $\alpha$ increased significantly at $24 \mathrm{~h}$ post-ROSC indicating that increasing IL-10 concentrations at the same time might counteract the increase of pro-inflammatory cytokines such as IL- $1 \alpha$, IL- $1 \beta$ and TNF- $\alpha$.

Overall, serum cytokine concentrations were not significantly altered except for a significant increase in IL-1 $\beta$ after $24 \mathrm{~h}$ post-ROSC. Additionally, IL- $1 \alpha, \mathrm{IL}-1 \beta, \mathrm{IL}-10$ and TNF- $\alpha$ concentrations were lower in serum than in the jejunum. This may indicate that the observed intestinal inflammation may not be associated with systemic inflammation.

Notably, intestinal cytokine increments were in accordance with morphological changes of the intestinal mucosa. Intestinal tissue damage peaked at $6 \mathrm{~h}$ post-ROSC and decreased subsequently at $24 \mathrm{~h}$ and $72 \mathrm{~h}$. Tissue repair mechanisms accompanied by increases in intestinal inflammatory cytokine release seem to have been initiated. Consequently, desquamation of villus tips, development of a Gruenhagen's space, hydropic generation of epithelial cells and changes in muscular layer thickness were observed.

The mechanism, which induces a further increase in intestinal tissue damage $7 \mathrm{~d}$ post-ROSC, accompanied by rising cytokine concentrations of IL- $1 \beta$ and IL-10 at the same timepoint, requires further research. As the duration between $72 \mathrm{~h}$ and $7 \mathrm{~d}$ post-ROSC is comparably long, it might be possible that further changes in cytokine concentrations remained undetected.

\section{Conclusions}

Six minutes of transient systemic ischaemia and reperfusion resulted in mild small intestinal tissue damage but not in systemic inflammation. A rat model of 6 min CA is not capable of mimicking a PCAS. Whether there is a vital influence of the intestine on the PCAS still remains unclear and should be investigated in further studies.

\section{Additional file}

Additional file 1: Duration of cardiac arrest in the different post-ROSC groups. One-way ANOVA $p<0.05$. Tukey's multiple comparison test did not show any statistically significant differences between any of the groups. (DOCX $28 \mathrm{~kb})$

\section{Abbreviations}

ATP: Adenosine triphosphate; CA : Cardiac arrest; CPR: Cardio-pulmonary resuscitation; IL: Interleukin; NMDA: N-methyl-D-aspartate receptor; 
PCAS: Post cardiac arrest syndrome; ROS: Reactive oxygen species; ROSC: Return of spontaneous circulation; TNF-a: Tumor necrosis factor-a

\section{Acknowledgements}

The authors thank Irmgard Henke and Malte Heykants for their excellent technical assistance, Roland Galmabcher, Peter Teschendorf and Andreas Schneider for their methodological support and Laura A. Webb, M.Sc. for proof-reading the manuscript.

\section{Funding}

This work was supported by the intramural "Cologne-Fortune" programme, Faculty of Medicine, University of Cologne (299/2014). Design of the study, collection, analysis, interpretation of data and writing were not influenced by thy funding body.

\section{Availability of data and materials}

The datasets used and/or analysed during the current study are available from the corresponding author on reasonable request.

\section{Authors' contributions}

DS and MG were involved in planning and conduction of the experiments, analysis and writing. $A M, X Y$ and IBM were involved in conduction of the experiments. EM, XY and IK carried out the Luminex-assays. SP, HH and ASK were involved in statistical analysis and interpretation of the data. EM, TA, TH, BWB and SP were involved in writing. All authors read and approved the final manuscript.

\section{Ethics approval}

All procedures were ethically approved by the appropriate governmental authority (Landesamt für Natur, Umwelt und Verbraucherschutz NordrheinWestfalen, LANUV, Germany, AZ: 8.87-51.04.20.09.368) and were in accordance with the German Animal Welfare Law. The manuscript complies with the Animals in Research: Reporting In Vivo Experiments (ARRIVE) guidelines

\section{Competing interests}

Independent from the presented work, TA received research funding from the Center of Integrated Oncology Cologne-Bonn, cytosorbents, Pulsion, Corpuls. The other authors declare that there is no conflict of interest.

\section{Publisher's Note}

Springer Nature remains neutral with regard to jurisdictional claims in published maps and institutional affiliations.

\section{Author details}

'Department of Anaesthesiology and Intensive Care Medicine, University Hospital of Cologne, Kerpener Str. 62, Cologne, Germany. ${ }^{2}$ Experimental Medicine, University Hospital of Cologne, Robert-Koch-Str.10, Cologne, Germany. ${ }^{3}$ Comparative Medicine, Center for Molecular Medicine Cologne, University of Cologne, Robert-Koch-Str.21, Cologne, Germany. ${ }^{4}$ Decentral Animal Facility, University Hospital of Cologne, Robert-Koch-Str.10, Cologne, Germany.

\section{Received: 5 September 2017 Accepted: 25 May 2018}

Published online: 05 June 2018

\section{References}

1. Elbers PW, Craenen AJ, Driessen A, Stehouwer MC, Munsterman L, Prins M, van Iterson $M$, Bruins $P$, Ince $C$. Imaging the human microcirculation during cardiopulmonary resuscitation in a hypothermic victim of submersion trauma. Resuscitation. 2010;81(1):123-5.

2. Padosch SA, Vogel P, Böttiger BW. Neuronale Apoptose nach zerebraler IschämieGrundlagen. Pathophysiologie und Interventionsmöglichkeiten Der Anaesthesist. 2001:50(12):905-20.

3. Chalkias A, Xanthos T. Pathophysiology and pathogenesis of post-resuscitation myocardial stunning. Heart Fail Rev. 2012;17(1):117-28.

4. Moulaert VR, Verbunt JA, van Heugten CM, Wade DT. Cognitive impairments in survivors of out-of-hospital cardiac arrest: a systematic review. Resuscitation. 2009;80(3):297-305

5. Adrie C, Adib-Conquy M, Laurent I, Monchi M, Vinsonneau C, Fitting C, Fraisse F, Dinh-Xuan AT, Carli P, Spaulding C, et al. Successful cardiopulmonary resuscitation after cardiac arrest as a "sepsis-like" syndrome. Circulation. 2002;106(5):562-8

6. Nolan JP, Neumar RW, Adrie C, Aibiki M, Berg RA, Bottiger BW, Callaway C, Clark RS, Geocadin RG, Jauch EC, et al. Post-cardiac arrest syndrome: epidemiology, pathophysiology, treatment, and prognostication. A scientific statement from the international liaison committee on resuscitation; the American Heart Association emergency cardiovascular care committee; the council on cardiovascular surgery and anesthesia; the council on cardiopulmonary, perioperative, and critical care; the council on clinical cardiology; the council on stroke. Resuscitation. 2008;79(3):350-79.

7. Carr GE, Yuen TC, McConville JF, Kress JP, VandenHoek TL, Hall JB, Edelson DP. Early cardiac arrest in patients hospitalized with pneumonia: a report from the American Heart Association's get with the guidelines-resuscitation program. Chest. 2012;141(6):1528-36.

8. Coba V, Jaehne AK, Suarez A, Dagher GA, Brown SC, Yang JJ, Manteuffel J, Rivers EP. The incidence and significance of bacteremia in out of hospital cardiac arrest. Resuscitation. 2014;85(2):196-202.

9. Guschlbauer M, Feige K, Geburek F, Hoppe S, Hopster K, Propsting MJ, Huber K. Effects of in vivo lidocaine administration at the time of ischemia and reperfusion on in vitro contractility of equine jejunal smooth muscle. Am J Vet Res. 2011;72(11):1449-55.

10. Guschlbauer M, Hoppe S, Geburek F, Feige K, Huber K. In vitro effects of lidocaine on the contractility of equine jejunal smooth muscle challenged by ischaemia-reperfusion injury. Equine Vet J. 2010;42(1):53-8.

11. Brencher $L$, Verhaegh $R$, Kirsch $M$. Attenuation of intestinal ischemiareperfusion-injury by beta-alanine: a potentially glycine-receptor mediated effect. J Surg Res. 2017;211:233-41.

12. Fink MP. Intestinal epithelial hyperpermeability: update on the pathogenesis of gut mucosal barrier dysfunction in critical illness. Curr Opin Crit Care. 2003;9(2):143-51.

13. Lenaerts K, Ceulemans $L$, Hundscheid IH, Grootjans J, Dejong $\mathrm{CH}$, Olde Damink SW. New insights in intestinal ischemia-reperfusion injury: implications for intestinal transplantation. Current opinion in organ transplantation. 2013:18(3):298-303.

14. Paterno F, Longo WE. The etiology and pathogenesis of vascular disorders of the intestine. Radiol Clin N Am. 2008:46(5):877-85.

15. Geng Y, Li J, Wang F, Li Q, Wang X, Sun L, Li W. Epidermal growth factor promotes proliferation and improves restoration after intestinal ischemiareperfusion injury in rats. Inflammation. 2013;36(3):670-9.

16. Bottiger BW, Schmitz B, Wiessner C, Vogel P, Hossmann KA. Neuronal stress response and neuronal cell damage after cardiocirculatory arrest in rats. Journal of cerebral blood flow and metabolism : official journal of the International Society of Cerebral Blood Flow and Metabolism. 1998;18(10):1077-87.

17. Ryan TJ, Anderson JL, Antman EM, Braniff BA, Brooks NH, Califf RM, Hillis LD, Hiratzka LF, Rapaport E, Riegel BJ, et al. ACC/AHA guidelines for the management of patients with acute myocardial infarction: executive summary. A report of the American College of Cardiology/American Heart Association task force on practice guidelines (committee on Management of Acute Myocardial Infarction). Circulation. 1996;94(9):2341-50.

18. Bottiger BW, Krumnikl JJ, Gass P, Schmitz B, Motsch J, Martin E. The cerebral 'no-reflow' phenomenon after cardiac arrest in rats-influence of low-flow reperfusion. Resuscitation. 1997;34(1):79-87.

19. Chiu CJ, McArdle AH, Brown R, Scott HJ, Gurd FN. Intestinal mucosal lesion in low-flow states. I. A morphological, hemodynamic, and metabolic reappraisal. Archives of surgery (Chicago, III : 1960). 1970;101(4):478-83.

20. Kilkenny C, Browne WJ, Cuthill IC, Emerson M, Altman DG. Improving bioscience research reporting: the ARRIVE guidelines for reporting animal research. PLoS Biol. 2010;8(6):e1000412.

21. Knapp J, Roewer J, Bruckner T, Bottiger BW, Popp E. Evaluation of cyclosporine a as a cardio- and neuroprotective agent after cardiopulmonary resuscitation in a rat model. Shock. 2015;43(6):576-81.

22. Qian J, Yang Z, Cahoon J, Xu J, Zhu C, Yang M, Hu X, Sun S, Tang W. Post-resuscitation intestinal microcirculation: its relationship with sublingual microcirculation and the severity of post-resuscitation syndrome. Resuscitation. 2014;85(6):833-9.

23. Hernandez LA, Grisham MB, Twohig B, Arfors KE, Harlan JM, Granger DN. Role of neutrophils in ischemia-reperfusion-induced microvascular injury. Am J Phys. 1987:253(3 Pt 2):H699-703.

24. Teschendorf P, Peter C, Albertsmeier M, Popp E, Walther A, Böttiger BW. In-vivo videomicroscopy of mesenteric postcapillary venules after cardiac arrest in rats: A-200. European Journal of Anaesthesiology (EJA). 2005;22:55. 
25. Bro-Jeppesen J, Johansson PI, Kjaergaard J, Wanscher M, Ostrowski SR, Bjerre M, Hassager C. Level of systemic inflammation and endothelial injury is associated with cardiovascular dysfunction and vasopressor support in post-cardiac arrest patients. Resuscitation. 2017;121:179-86.

26. Schneider A, Albertsmeier M, Bottiger BW, Teschendorf P. Post-resuscitation syndrome. Role of inflammation after cardiac arrest. Anaesthesist. 2012; 61(5):424-36.

27. Traystman RJ, Kirsch JR, Koehler RC. Oxygen radical mechanisms of brain injury following ischemia and reperfusion. Journal of applied physiology (Bethesda, Md : 1985). 1991;71(4):1185-95.

28. Hossmann K-A. Pathophysiology and therapy of experimental stroke. Cell Mol Neurobiol. 2006;26(7):1055-81.

29. Liu T, Zhang L, Joo D, Sun S-C. NF-KB signaling in inflammation. Signal Transduction And Targeted Therapy. 2017;2:17023.

30. Negovsky VA, Gurvitch AM. Post-resuscitation disease-a new nosological entity. Its reality and significance. Resuscitation. 1995;30(1):23-7.

31. Papadimitriou D, Xanthos T, Dontas I, Lelovas P, Perrea D. The use of mice and rats as animal models for cardiopulmonary resuscitation research. Lab Anim. 2008:42(3):265-76.

32. Knapp J, Heinzmann A, Schneider A, Padosch SA, Bottiger BW, Teschendorf P, Popp E. Hypothermia and neuroprotection by sulfide after cardiac arrest and cardiopulmonary resuscitation. Resuscitation. 2011;82(8):1076-80.

33. Knapp J, Teschendorf P, Scholz E, Roewer J, Russ N, Bottiger BW, Popp E. Conductance catheter measurement and effect of different anesthetics in a rat model of postresuscitation myocardial dysfunction. Journal of the American Association for Laboratory Animal Science : JAALAS. 2014:53(4):392-8.

34. Schneider A, Teschendorf P, Vogel P, Russ N, Knapp J, Bottiger BW, Popp E. Facilitation of hypothermia by quinpirole and 8-OH-DPAT in a rat model of cardiac arrest. Resuscitation. 2012;83(2):232-7.

35. Vognsen M, Fabian-Jessing BK, Secher N, Lofgren B, Dezfulian C, Andersen LW, Granfeldt A. Contemporary animal models of cardiac arrest: a systematic review. Resuscitation. 2017;113:115-23.

36. Pan H, Chen D, Liu B, Xie X, Zhang J, Yang G. Effects of sodium hydrosulfide on intestinal mucosal injury in a rat model of cardiac arrest and cardiopulmonary resuscitation. Life Sci. 2013:93(1):24-9.

37. Drabek T, Foley LM, Janata A, Stezoski J, Kevin Hitchens T, Manole MD, Kochanek PM. Global and regional differences in cerebral blood flow after asphyxial versus ventricular fibrillation cardiac arrest in rats using ASL-MRI. Resuscitation. 2014;85(7):964-71.

38. Kagstrom E, Smith ML, Siesjo BK. Local cerebral blood flow in the recovery period following complete cerebral ischemia in the rat. Journal of cerebral blood flow and metabolism : official journal of the International Society of Cerebral Blood Flow and Metabolism. 1983;3(2):170-82.

39. Chalkias A, Scheetz MH, Gulati A, Xanthos T. Periarrest intestinal bacterial translocation and resuscitation outcome. J Crit Care. 2016;31(1):217-20.

40. Chen GY, Nunez G. Sterile inflammation: sensing and reacting to damage. Nat Rev Immunol. 2010;10(12):826-37.

41. Garlanda C, Dinarello CA, Mantovani A. The interleukin-1 family: back to the future. Immunity. 2013;39(6):1003-18.

42. Berda-Haddad Y, Robert S, Salers P, Zekraoui L, Farnarier C, Dinarello CA Dignat-George F, Kaplanski G. Sterile inflammation of endothelial cell-derived apoptotic bodies is mediated by interleukin-1alpha. Proc Natl Acad Sci U S A. 2011;108(51):20684-9.

43. Ouyang W, Rutz S, Crellin NK, Valdez PA, Hymowitz SG. Regulation and functions of the IL-10 family of cytokines in inflammation and disease. Annu Rev Immunol. 2011;29:71-109.

44. Chiu CJMA, Brown R, et al. A morphologic, hemodynamic and metabolic reappraisal. Arch Surg. 1970;101:290-7.

\section{Ready to submit your research? Choose BMC and benefit from:}

- fast, convenient online submission

- thorough peer review by experienced researchers in your field

- rapid publication on acceptance

- support for research data, including large and complex data types

- gold Open Access which fosters wider collaboration and increased citations

- maximum visibility for your research: over $100 \mathrm{M}$ website views per year

At BMC, research is always in progress.

Learn more biomedcentral.com/submissions 